\title{
The effect of increased blood pressure on hemispheric lactate and water content during acute cerebral ischaemia in the rat and gerbil
}

\author{
B S ASPEY, S EHTESHAMI, C M HURST, A L MCCOY, M J G HARRISON \\ From the Department of Neurological Studies, The Middlesex Hospital Medical School, London, UK
}

SUMMARY Infusions of metaraminol and angiotensin were used to test the effect of increased perfusion pressure on tissue metabolism and oedema after induction of regional cerebral ischaemia in the rat and the gerbil. An increase of mean arterial blood pressure of $30-40 \mathrm{mmHg}$ in the rat over the first 2 hours after diathermy of the middle cerebral artery prevented the $100 \%$ rise in hemisphere lactate seen in normotensive control animals. Angiotensin infusion also prevented early hemispheric oedema in this model. In the gerbil, 4 hours after placing a clip on one carotid artery, metaraminolinduced increases in blood pressure had no such protective effect on the metabolic changes or on oedema. When the clip was removed after 3 hours to permit 1 hour of reperfusion, lactate levels returned to normal but the degree of oedema was unchanged. Hypertension in this reperfusion model caused a slight but not statistically significant increase in oedema. The evidence suggests that moderate increases in blood pressure may be protective against the early metabolic sequelae of focal cerebral ischaemia, but there are potential problems with oedema formation. It is argued that a clinical trial should study the potentially beneficial effects of a brief early increase in blood pressure in the acute aftermath of ischaemic stroke.

The existence of a temporary penumbral zone around an area of focal ischaemia in which local blood flow is sufficient to maintain neuronal structure and viability, but not function ${ }^{1}$ suggests that therapy directed towards its salvage might improve outcome. Recent experimental work has concentrated on the use of metabolic inhibitors to reduce substrate requirements, and vaso-active materials. Since autoregulation of cerebral blood flow is impaired in the ischaemic territory ${ }^{2}$ improvement of perfusion might be possible by increasing perfusion pressure.

Several anecdotal clinical reports have suggested that induced hypertension may benefit stroke victims. $^{3-5}$ However, most experimental studies have highlighted the potential dangers due to an increase in vasogenic oedema if perfusion pressure is increased at a time when the blood brain barrier is damaged. ${ }^{6-10}$

Address for reprint requests: Mr B S Aspey, Department of Neurological Studies, the Middlesex Hospital Medical School, Mortimer Street, London, W1N 8AA, UK.

Received 7 November 1986 and in revised form 26 March 1987. Accepted 2 April 1987
Vasogenic oedema does not develop at once after the onset of regional cerebral ischaemia, however, being delayed some hours in animal models, ${ }^{11}$ and perhaps by 24-72 hours in man. ${ }^{12}$ It seemed to us therefore that brief early induced hypertension might improve the metabolic consequences of acute cerebral ischaemia and avoid the risks of aggravating subsequent oedema. If the ischaemic damage could be reduced, early cytotoxic oedema might also be reduced.

To this end we have investigated the effect of acute increases in blood pressure in two animal models of regional cerebral ischaemia: occlusion of the common carotid artery and contralateral external carotid artery in the gerbil, ${ }^{13}$ and middle cerebral artery occlusion in the rat. ${ }^{14}$ We have measured whole hemisphere lactate content in the belief that this should reflect the depth and extent of ischaemic metabolic derangement $^{15}$ and hemispheric wet weight/dry weight differences to assess the degree of hemispheric oedema. ${ }^{16}$ We used both metaraminol and angiotensin to maintain moderate elevations of blood pressure to distinguish between the haemodynamic and any other pharmacological effects of the drugs. ${ }^{10}$ 
Methods

Rat: middle cerebral artery occlusion

Male Sprague-Dawley rats $(350-650 \mathrm{~g})$ were allowed free access to food and water prior to induction of anaesthesia with ether. Surgical anaesthesia was maintained with intraperitoneal urethane (Sigma Chemical Co. Ltd.) $1.25 \mathrm{~g} / \mathrm{kg}$ as $25 \%$ solution in normal saline. The right femoral artery was cannulated for arterial blood sampling and blood pressure recording, and the left femoral vein cannulated for infusions. A tracheostomy was performed and the left common carotid artery ligated. Body temperature was monitored by a rectal probe and maintained by a lamp and by ice packs (in the case of metaraminol treatment).

After physiological baseline values were established for arterial blood pressure, $\mathrm{pCO}_{2}, \mathrm{pO}_{2}, \mathrm{pH}$ and glucose, the zygoma was removed and a limited craniotomy carried out to visualise the left middle cerebral artery. ${ }^{1417}$ The vessel was diathermied just above the site where it crossed the lateral margin of the olfactory tract.

The animals were then divided into three groups, the first receiving a continuous intravenous infusion of angiotensin II (Hypertensin Ciba, Ciba-Geigy Ltd.) $(\sim 100 \mu \mathrm{g} / \mathrm{kg} / \mathrm{min})$ to maintain mean arterial blood pressure $30-40 \mathrm{mmHg}$ above the pre-occlusion level, for the following 2 hours. A second group received an infusion of metaraminol bitartrate (Aramine; Merck, Sharpe and Dohme Ltd.) in normal saline ( $\sim 20 \mu \mathrm{g} / \mathrm{kg} / \mathrm{min}$ ) to produce a similar elevation of pressure. The third control group received no such infusions. All groups also received $2 \mathrm{ml}$ of normal saline intravenously over the first 30 minutes after occlusion as part of another protocol.

At the end of 2 hours animals were killed either by intravenous air embolism for measurement of brain wet weight/dry weight determination, or by immersion in liquid nitrogen for brain lactate assay (vide infra.). Normal values were obtained from animals anaesthetised for sham operations. Three were given metaraminol to assess any direct effect of drug induced hypertension on brain lactate.

\section{Gerbils: carotid ligation}

Mongolian gerbils of either sex $(50-80 \mathrm{~g})$ were similarly given access to water and food prior to anaesthetising with intraperitoneal sodium pentobarbitone $60 \mathrm{mg} / \mathrm{kg}$ (Sagatal, May \& Baker). A tracheostomy was performed; the right external carotid artery was ligated and the left common carotid artery was either permanently ligated for 4 hours or temporarily occluded by a Scoville Lewis aneurysm clip for 3 hours, recirculation being permitted for 1 hour subsequently. Arterial blood pressure was monitored via a femoral cannula from which a $50 \mu \mathrm{l}$ sample was removed for blood glucose estimation. Body temperature was again maintained by a heat lamp. Blood pressure was elevated by approximately $30 \mathrm{mmHg}$ in half the animals by intramuscular injections of metaraminol bitartrate $(0.02-0.03 \mathrm{ml}$ of a $1.6 \mathrm{mg} / \mathrm{ml}$ solution in saline to give $1 \mathrm{mg} / \mathrm{kg}$ ). Further injections of $0.5 \mathrm{mg} / \mathrm{kg}$ were repeated during the 4 hours of the experiment to maintain blood pressure above the preocclusion range.

Animals were killed after 4 hours by decapitation for cerebral water content determination, or by immersion in liquid nitrogen for hemispheric lactate assay. Normal values of gerbil hemispheric lactate were obtained from six animals anaesthetised for sham operations with sodium pentobarbitone for 4 hours, three of which were also made hypertensive with metaraminol.

Assays of hemispheric water content: In both rats and gerbils the brains were rapidly removed and each cerebral hemisphere separated from the hind brain and from the olfactory lobes and its wet weight determined. They were then dried at room temperature under vacuum in a dessicator for at least 48 hours and the dry weight of each hemisphere recorded. The percentage tissue swelling of the ischaemic left hemisphere was calculated according to Elliott and Jasper. ${ }^{16}$

Hemispheric Lactate: The heads were stored at $-70^{\circ} \mathrm{C}$ until required when the brain was chiselled out and each hemisphere ground to a fine powder in further liquid nitrogen. This was immediately vortexed in ice-cold $8 \%$ perchloric acid (approximately $60 \mathrm{ml} / \mathrm{g}$ of dried brain), kept on ice for 30 minutes and then centrifuged at $1600 \mathrm{~g}$ for 10 minutes. The supernatant was then used in a standard lactate assay (Sigma Chemical Co. Ltd.). The residue was solubilised in $0.5 \mathrm{M}$ sodium hydroxide (approximately $60 \mathrm{ml} / \mathrm{g}$ of dried brain) and assayed for protein. ${ }^{18}$ Crystalline bovine serum albumin (Sigma Chemical Co. Ltd.) was used to produce a standard assay curve for each batch of samples. Duplicate assays were carried out on each sample. The mean hemispheric protein content in the control hemispheres were 70.8 (SD 13.0) $\mathrm{mg}$ in the rat, and 22.3 (SD 4.2) $\mathrm{mg}$ in the gerbil. Lactate values for each hemisphere were expressed in $\mu \mathrm{mol} / \mathrm{mg}$ of hemispheric protein \pm one standard deviation (SD). The percentage rise in lactate in the left hemisphere was calculated with respect to the right hemispheric value for each animal by the following formula:

$\%$ rise $=\frac{\text { left hemisphere lactate }- \text { right hemisphere lactate }}{\text { right hemisphere lactate }} \times 100$ Student's $t$ test was used to calculate statistical significance.

\section{Results}

Rat model (tables 1,2,3)

Pre-occlusion values for arterial blood pressure, $\mathrm{pCO}_{2}, \mathrm{PO}_{2}, \mathrm{pH}$ and glucose were all within normal ranges (table 1). In six untreated animals with postocclusion blood pressures averaging $90 \mathrm{mmHg}$, left hemispheric lactate at 2 hours was $0.083 \pm 0.019$ $\mu \mathrm{mol} / \mathrm{mg}$ protein, a mean rise of $116 \%$ (table 2 ). In six animals given angiotensin, blood pressures were continuously elevated by approximately $35 \mathrm{mmHg}$ and the mean percentage rise in lactate in the left hemisphere was significantly reduced $(p<0.05)$. Right hemispheric lactate values in both groups were not significantly different from the sham operated rats. The extent of left hemispheric oedema as measured by percentage tissue swelling was $1.27 \pm 1.5 \%$ in six untreated normotensive animals (table 3 ). In another six animals given angiotensin, elevating blood pressure by approximately $45 \mathrm{mmHg}$, percentage tissue swelling averaged $-0.33 \pm 0.81 \%(p<0.05)$. With metaraminol infusion, causing a similar rise in postocclusion blood pressure, left hemispheric lactate was 
The effect of increased blood pressure on hemispheric lactate and water content during acute cerebral ischaemia in the rat and gerbil

Table 1 Pre-operative physiological variables in the rat $( \pm S D)$

\begin{tabular}{|c|c|c|c|c|c|c|}
\hline \multirow[b]{2}{*}{ Group } & \multirow[b]{2}{*}{$\begin{array}{l}\text { Temp } \\
{ }^{\circ} \mathrm{C}\end{array}$} & \multirow{2}{*}{$\begin{array}{l}\text { Blood } \\
\text { glucose } \\
m M l^{-1}\end{array}$} & \multirow[b]{2}{*}{$\begin{array}{l}B P \\
m m H g\end{array}$} & \multicolumn{3}{|l|}{ Arterial } \\
\hline & & & & $\begin{array}{l}\mathrm{pO}_{2} \\
\mathrm{~mm} \mathrm{Hg}\end{array}$ & $\begin{array}{l}p \mathrm{CO}_{2} \\
\mathrm{mmHg}\end{array}$ & $p H$ \\
\hline Control & $\begin{array}{l}36.7 \\
(0.8)\end{array}$ & $\begin{array}{l}10 \cdot 7 \\
(0.8)\end{array}$ & $\begin{array}{c}95 \\
(20)\end{array}$ & $\begin{array}{c}99 \cdot 3 \\
(9 \cdot 0)\end{array}$ & $\begin{array}{l}41 \cdot 6 \\
(2 \cdot 8)\end{array}$ & $\begin{array}{l}7 \cdot 36 \\
(0.03)\end{array}$ \\
\hline Angiotensin & $\begin{array}{l}36 \cdot 8 \\
(0 \cdot 5)\end{array}$ & $\begin{array}{l}11 \cdot 3 \\
(0.6)\end{array}$ & $\begin{array}{r}85 \\
(15)\end{array}$ & $\begin{array}{c}98 \cdot 1 \\
(15 \cdot 7)\end{array}$ & $\begin{array}{l}40 \cdot 1 \\
(3 \cdot 5)\end{array}$ & $\begin{array}{l}7 \cdot 36 \\
(0.02)\end{array}$ \\
\hline Aramine & $\begin{array}{l}36 \cdot 7 \\
(0 \cdot 8)\end{array}$ & $\begin{array}{l}10.6 \\
(0.6)\end{array}$ & $\begin{array}{l}100 \\
(15)\end{array}$ & $\begin{array}{c}95.8 \\
(16.8)\end{array}$ & $\begin{array}{l}41 \cdot 2 \\
(4 \cdot 9)\end{array}$ & $\begin{array}{l}7 \cdot 34 \\
(0 \cdot 02)\end{array}$ \\
\hline Sham op'n & $\begin{array}{l}36 \cdot 3 \\
(0 \cdot 2)\end{array}$ & $\begin{array}{l}11 \cdot 6 \\
(0 \cdot 2)\end{array}$ & $\begin{array}{l}90 \\
(5)\end{array}$ & $\begin{array}{c}99 \cdot 8 \\
(7 \cdot 4)\end{array}$ & $\begin{array}{l}41 \cdot 3 \\
(1 \cdot 5)\end{array}$ & $\begin{array}{l}7 \cdot 35 \\
(0.02)\end{array}$ \\
\hline $\begin{array}{l}\text { Sham op'n } \\
\text { + aramine }\end{array}$ & $\begin{array}{l}36.9 \\
(0 \cdot 1)\end{array}$ & $\begin{array}{l}10 \cdot 2 \\
(1 \cdot 7)\end{array}$ & 110 & $\begin{array}{l}107 \cdot 5 \\
(11 \cdot 9)\end{array}$ & $\begin{array}{l}41 \cdot 2 \\
(1 \cdot 8)\end{array}$ & $\begin{array}{l}7 \cdot 35 \\
(0.02)\end{array}$ \\
\hline
\end{tabular}

Table 2 Effect of aramine and angiotensin on hemispheric lactate $2 \mathrm{~h}$ after occlusion of the left middle cerebral artery in the rat $( \pm S D)$

\begin{tabular}{|c|c|c|c|c|c|}
\hline \multirow[b]{2}{*}{ Group } & \multicolumn{2}{|l|}{$\mathrm{BP} \mathrm{mmHg}$} & \multicolumn{3}{|c|}{ Lactate $\mu \mathrm{mol} / \mathrm{mg}$ protein } \\
\hline & Mean post occl. & Change & $L$ & $\boldsymbol{R}$ & Rise [\%] \\
\hline $\begin{array}{c}\text { Control } \\
(n=6) \\
\text { Angiotensin } \\
(n=6) \\
\text { Aramine } \\
(n=6)\end{array}$ & $\begin{array}{l}90 \\
(15) \\
120 \\
(15) \\
140 \\
(10)\end{array}$ & $\begin{array}{l}-10 \\
(5) \\
+35 \\
(15) \\
+40 \\
(10)\end{array}$ & $\begin{array}{l}0.083 \ddagger \\
(0.019) \\
0.054 \\
(0.016) \\
0.042 \\
(0.011)\end{array}$ & $\begin{array}{l}0.039 \\
(0.013) \\
0.040 \\
(0.013) \\
0.057 \\
(0.012)\end{array}$ & $\begin{array}{l}116 \\
(30 \cdot 5) \\
42^{*} \\
(52) \\
-26 \dagger \\
(13)\end{array}$ \\
\hline $\begin{array}{l}\text { Sham } \\
\quad(n=3) \\
\text { Sham }+ \text { aramine } \\
(n=3)\end{array}$ & & & & & \\
\hline
\end{tabular}

${ }^{*}$ Difference from control $p<0.05$. †Difference from control $p<0.01$. †Difference between $L$ and $R$ hemisphere $p<0.001$.

Table 3 Effect of angiotensin on hemispheric water content $2 \mathrm{~h}$ after occlusion of the left middle cerebral artery in the rat $( \pm S D)$

\begin{tabular}{|c|c|c|c|c|c|}
\hline \multirow[b]{2}{*}{ Group } & \multicolumn{2}{|l|}{$B P \mathrm{mmHg}$} & \multicolumn{2}{|c|}{ Water content $\%$} & \multirow[b]{2}{*}{ Tissue swelling \% } \\
\hline & Mean post occl. & Change & $L$ & $R$ & \\
\hline $\begin{array}{l}\text { Control } \\
(n=6) \\
\text { Angiotensin } \\
(n=6)\end{array}$ & $\begin{array}{l}90 \\
(5) \\
160 \\
(35)\end{array}$ & $\begin{array}{l}-10 \\
(10) \\
+45 \\
(15)\end{array}$ & $\begin{array}{l}76 \cdot 8 \\
(0 \cdot 5) \\
76 \cdot 2 \\
(0 \cdot 6)\end{array}$ & $\begin{array}{l}76 \cdot 5 \\
(0 \cdot 4) \\
76 \cdot 2 \\
(0 \cdot 6)\end{array}$ & $\begin{array}{l}1.27 \\
(1.5) \\
-0.33^{*} \\
(0.81)\end{array}$ \\
\hline
\end{tabular}

${ }^{*}$ Difference from control $\mathrm{p}<0.05$.

if anything less than that on the non-ischaemic side (table 2). Sham operated animals given metaraminol showed a small but significant rise in hemispheric lactate compared with untreated shams, however.

\section{Gerbil model (table 4,5)}

Four hours after carotid ligation, 10 untreated gerbils with post-occlusion blood pressures averaging 65 $\mathrm{mmHg}$ had a mean left hemispheric lactate value of $0.062 \pm 0.04 \mu \mathrm{mol} / \mathrm{mg}$ protein, representing a mean percentage rise of $63.3 \%$ above the right hemisphere $(p<0.05)$. In 10 animals given metaraminol to maintain blood pressure approximately $30 \mathrm{mmHg}$ above pre-occlusion values, the mean percentage rise in lactate was $98.9 \%$ (table 4). However, the range of values in both groups was quite wide (cf.Djuricic ${ }^{15}$ ), and there was no significant difference between them. Right hemispheric lactate values in both groups were similar to sham operated gerbils. Metaraminol made no difference to the lactate values in the latter animals. Following 3 hours of occlusion and 1 hour reperfusion, lactate levels were symmetrical and not significantly different from the shams. Metaraminol made no difference to these findings. In all four experimental groups assessing hemispheric oedema (table 5), mean left hemisphere water content and per- 
Table 4 Effect of aramine on hemispheric lactate content after carotid ligation in the gerbil $( \pm S D)$

\begin{tabular}{|c|c|c|c|c|c|c|c|}
\hline \multirow[b]{2}{*}{ Group } & \multirow{2}{*}{$\begin{array}{l}\text { Duration } \\
\text { ischaemia hrs } \pm \\
\text { reperfusion }(R)\end{array}$} & \multicolumn{2}{|l|}{$B P \mathrm{mmHg}$} & \multirow{2}{*}{$\begin{array}{l}\text { Blood glucose } \\
m M l^{-1}\end{array}$} & \multicolumn{3}{|c|}{ Lactate $\mu \mathrm{mol} / \mathrm{mg}$ protein } \\
\hline & & Mean post occl. & Rise & & $L$ & $R$ & Rise \% \\
\hline Hypertensive & & 85 & +30 & 4.9 & $0.084 * \dagger$ & 0.044 & 98.9 \\
\hline Control & $\begin{array}{l}n=10 \\
3+1 R \\
n=10\end{array}$ & $\begin{array}{l}(10) \\
60 \\
(10)\end{array}$ & $\begin{array}{l}(5) \\
-15 \\
(15)\end{array}$ & $\begin{array}{l}(0 \cdot 6) \\
6 \cdot 7 \\
(1.6)\end{array}$ & $\begin{array}{l}(0.05) \\
0.04 \\
(0.01)\end{array}$ & $\begin{array}{l}(0.02) \\
0.036 \\
(0.006)\end{array}$ & $\frac{(136)}{-}$ \\
\hline Hypertensive & $\begin{array}{l}3+1 R \\
n=10\end{array}$ & $\begin{array}{l}90 \\
(5)\end{array}$ & $\begin{array}{l}+30 \\
(10)\end{array}$ & $\begin{array}{l}6 \cdot 2 \\
(1 \cdot 5)\end{array}$ & $\begin{array}{l}0.039 \\
(0.005)\end{array}$ & $\begin{array}{l}0.041 \\
(0.007)\end{array}$ & - \\
\hline Sham & $\mathrm{n}=3$ & & & & $\begin{array}{l}0.032 \\
(0.006)\end{array}$ & $\begin{array}{l}0.034 \\
(0.008)\end{array}$ & - \\
\hline
\end{tabular}

*Difference between $\mathrm{L}$ and $\mathrm{R}$ hemisphere significant at $\mathrm{p}<0.05$.

†Difference from results in sham operated animals significant at $\mathrm{p}<0.05$.

Table 5 Effect of aramine on hemispheric water content 4 h after carotid ligation in the gerbil $( \pm S D)$

\begin{tabular}{|c|c|c|c|c|c|c|}
\hline \multirow[b]{2}{*}{ Group } & \multirow{2}{*}{$\begin{array}{l}\text { Duration } \\
\text { ischaemia hrs } \pm \\
\text { reperfusion }(R)\end{array}$} & \multicolumn{2}{|l|}{$B P \mathrm{mmHg}$} & \multicolumn{2}{|c|}{ Water content $\%$} & \multirow[b]{2}{*}{ Tissue swelling \% } \\
\hline & & Mean post occl. & Rise & $L$ & $R$ & \\
\hline Control & 4 & 65 & -5 & $77 \cdot 7$ & $76 \cdot 8$ & $3 \cdot 6^{*}$ \\
\hline & $n=10$ & (10) & (5) & $(1 \cdot 0)$ & $(0.5)$ & $(5 \cdot 0)$ \\
\hline Aramine & & 90 & +25 & 76.9 & $75 \cdot 7$ & $4 \cdot 8^{*}$ \\
\hline & $\mathbf{n}=10$ & (5) & (10) & $(1 \cdot 3)$ & $(1 \cdot 3)$ & $(5 \cdot 6)$ \\
\hline Control & $3+1 \mathbf{R}$ & 65 & & $77 \cdot 8$ & 77.0 & $3 \cdot 3^{*}$ \\
\hline & $\mathrm{n}=10$ & (15) & (20) & $(1 \cdot 1)$ & $(1 \cdot 0)$ & $(3.9)$ \\
\hline Aramine & $3+1 \mathbf{R}$ & 90 & +25 & $77 \cdot 1$ & 75.8 & $5 \cdot 1^{*}$ \\
\hline & $\mathrm{n}=10$ & (5) & $(10)$ & $(1.4)$ & $(1 \cdot 6)$ & $(5 \cdot 9)$ \\
\hline Sham & $n=3$ & & & $\begin{array}{l}77 \cdot 8 \\
(0 \cdot 3)\end{array}$ & $\begin{array}{l}77 \cdot 7 \\
(0.3)\end{array}$ & 0.29 \\
\hline
\end{tabular}

*Difference from result in sham operated animals $\mathrm{p}<0.05$.

centage tissue swelling were significantly elevated above sham operated gerbils $(\mathrm{p}<0.05)$. Reperfusion had no effect on either parameter. However, hypertensive animals had the highest values for tissue swelling both after 4 hours ischaemia and 1 hour's reperfusion, but this difference did not achieve statistical significance.

\section{Discussion}

In the immediate aftermath of cerebral infarction, there is evident loss of autoregulation of cerebral blood flow both in man and in experimental animals. ${ }^{21619}$ As a result, flow is pressure passive, falling in the presence of hypotension. The possibility that an increase in perfusion pressure might ameliorate the ischaemic effects of occlusion of the carotid or middle cerebral artery has been voiced over the years but not often actively studied. ${ }^{2520}$ The generally disappointing results of medical therapy for ischaemic strokes ${ }^{21}$ prompted a further experimental study of the use of pressor agents.

One of the reasons for the cautious exploration of this line of therapy in the past has been the fear that infarction might be made haemorrhagic by an in- crease in blood pressure and that oedema might be aggravated. In the experimental animal hypertensio has been shown to increase vasogenic oedema. ${ }^{722} \mathrm{We}$ sought to avoid such complications by avoiding severe hypertension shown to be potentially deleterious ${ }^{8}$ and by only causing an increase in perfusion pressure for a limited time.

The choice of animal models requires some comment. The advantage of the rat model of regional cerebral ischaemia lies in the ability to produce a standard volume of infarction after middle cerebral artery occlusion. ${ }^{14}$ It was felt this would be the most suitable model in which to test the "protective" effect of an early increase in perfusion pressure. Once the blood brain barrier is opened hypertension aggravates vasogenic oedema, ${ }^{9}$ so we wished to study the period after middle cerebral artery occlusion before the onset of blood brain barrier damage. In the cat O'Brien showed that there was increased permeability to pertechnetate at 4 hours, ${ }^{23}$ and Tyson ${ }^{24}$ has recently demonstrated increased blood to brain transfer of ${ }^{14} \mathrm{C}$-aminobutyric acid in the rat 4 hours after middle cerebral artery occlusion, but only if hypotension aggravated the level of ischaemia. Hossmann ${ }^{25}$ had shown that oedema is well established by 2 hours in a 
The effect of increased blood pressure on hemispheric lactate and water content during acute cerebral ischaemia in the rat and gerbil

middle cerebral occlusion model, so we decided upon a 2 hour period of ischaemia in which oedema would be expected to play a role, but opening of the blood brain barrier was unlikely. In the event Evans Blue staining was not seen at 2 hours in our experiments confirming that there was no gross blood brain barrier damage at this time. Urethane was chosen as the anaesthetic for convenience during the complicated surgical procedure.

There is evidence in the literature ${ }^{24}$ that oedema is increased by reperfusion. As this is somewhat difficult to study in the rat we also looked at the effect of occlusion of one common carotid artery in the gerbil. This produces a more variable degree of ischaemia but reperfusion is easy to study after removal of the clip. Previous studies in our laboratory had shown no Evans Blue staining 4 hours after carotid occlusion even in hypertensive animals, so this was the period studied. Reperfusion can lead to enhanced leak of Evans Blue but even after severe global ischaemia in the gerbil this is unusual before 60 minutes of reperfusion. ${ }^{27}$ We therefore chose to study 1 hour's reperfusion after 3 hours ischaemia to compare with the effect of 4 hours ischaemia. Such a reperfusion model more closely mimicks the clinical situation of cerebral embolism in which the vascular obstruction may only be temporary. Pentobarbitone was used to anaesthetise the gerbils as this was the anaesthetic used in our previous studies, and those of Avery et al ${ }^{27}$ which had been influential in the design of the protocol. There was no reason to suppose the difference in anaesthetic would affect the response of ischaemia to increased perfusion pressure.

As the clinical sequelae and histological changes are difficult to quantify immediately after the onset of ischaemia we sought a metabolic marker of cerebral tissue ischaemia. To this end we chose to measure whole hemisphere lactate ${ }^{15}$ which should reflect the volume of tissue forced into anaerobic glycolysis by the depth of ischaemia. There is also evidence that elevated lactate levels may contribute to the damaging effects of ischaemia on tissue integrity, and on oedema formation. ${ }^{28}$

As severe hypertension can open the blood-brain barrier, ${ }^{2930}$ we chose to produce only a modest rise in mean arterial pressure. This was achieved with either metaraminol or intravenous infusions of angiotensin. The latter was not employed in the gerbil model to avoid fluid volume overload in the small animals.

In the rat our results show that an infusion of metaraminol or angiotensin to elevate the mean arterial blood pressure from $90-100 \mathrm{mmHg}$ to $120-140$ $\mathrm{mmHg}$ for 2 hours after middle cerebral artery occlusion was accompanied by a significant reduction in the lactate content of the ischaemic cerebral hemisphere. In fact, in animals with an elevated blood pressure, the hemisphere on the side of the middle cerebral artery occlusion had a lactate content insignificantly different from that on the intact side. This observation suggests that an increased perfusion pressure is capable of ameliorating the metabolic consequences of regional cerebral ischaemia, presumably by reducing the extent and/or depth of ischaemia through collateral flow. The fact that metaraminol and angiotensin both produced this result in the rat argues in favour of a direct effect of the induced hypertension rather than a pharmacological effect of the pressor agents.

The concern that oedema would be aggravated by hypertension was not borne out in the rat experiments; indeed the hypertensive animals given angiotensin showed an abolition of early hemisphere swelling. This finding is entirely compatible with the idea that early water accumulation is cytotoxic, that is, metabolic in origin, and can be reduced if the metabolic derangement induced by ischaemia can be moderated. ${ }^{31}$

The results in the gerbil are discordant. Metaraminol produced a comparable elevation of blood pressure to that in the rat, but there was no evidence of a reduction in lactate or cerebral oedema. The longer duration of ischaemia studied in the gerbil may have played a role with oedema contributing to an elevated intracranial pressure (ICP) and mitigating against better hemisphere perfusion. There is less chance of raised ICP in the rat with a small volume of ischaemic tissue and an open skull when compared with a gerbil model, which had a closed skull and, in at least some animals, ischaemia affects a large proportion of the hemisphere.

Other possible factors include a species difference in the pharmacological effects of the pressor agents. Metaraminol caused an increase in hemisphere lactate in the rat in sham operated animals, though not in the gerbil, though the pressor effect seems to have overcome this potentially adverse change in the ischaemic rats.

In the literature several reports have noted dramatic short term improvement in patients with ischaemic cerebral deficits as a result of infusions of levophed, angiotensin or dopamine. Shanbrom and Levy in $1957^{3}$ reported two patients whose neurological deficit came and went in parallel with the pressor effects of a norepinephrine infusion. Wise ${ }^{4}$ was sufficiently impressed by the response of a patient with hemiplegia following angiography to metaraminol that he went on to treat 13 patients with ischaemic stroke. ${ }^{5}$ Five patients with pressures of less than $140 / 80$ had pressor responses to $150-170$ systolic and 85-100 diastolic for a period of 3 hours. Their neurological signs improved only to return when blood pressure fell again. 
These anecdotal clinical reports and the experimental results reported provide a strong argument for a formal trial. Although early cytotoxic ischaemic oedema may be ameliorated by early pressor treatment later vasogenic oedema is likely to be aggravated. The time window during which an increase in perfusion pressure might be safe is probably measured in hours only. Although maximal oedema in ischaemic stroke is seen at 3-4 days ${ }^{1232}$ there is evidence that the blood-brain barrier is probably impaired in man within 24 hours $^{33}$ (and in animals within hours ${ }^{1134}$ ). The neurosurgical experience that dopamine can be safely used to reverse the ischaemic deficit complicating subarachnoid haemorrhage is based on its immediate use in patients whose deficit develops while under inpatient observation. ${ }^{3536}$ Any trial would have to exclude cases with haemorrhagic infarction or early mass effect with already elevated blood pressure, and who arrived at the emergency room more than say 8 hours after onset. Such limitations would make severe logistic demands on the trialist but the evidence seems clear that such an attempt should be made.

CM Hurst was partially supported by the Chest, Heart and Stroke Association. We are grateful to Ciba-Geigy Ltd. for supplies of angiotensin, and to initial technical assistance from Miss T Penman and Mr M Steiner. Dr David Cox of St Thomas's Hospital Medical School kindly advised on the protein and lactate assays.

\section{References}

1 Astrup J, Siesjo BK, Symon L. Thresholds in cerebral ischaemia-the ischaemic penumbra. Stroke 1981;12:723-5.

2 Symon L, Branston NM, Strong AJ. Autoregulation in acute focal ischaemia. An experimental study. Stroke 1976;7:547-54.

3 Shanbrom E, Levy $\mathrm{L}$. The role of systemic blood pressure in cerebral circulation in carotid and basilar artery thromboses. $\mathrm{Am} \mathrm{J}$ Med 1957;23:197-204.

4 Wise GR, Vasopressor-drug therapy for complications of cerebral arteriography. $N$ Engl J Med 1970;282:610-2.

5 Wise G, Sutter R, Burkholder J. The treatment of brain ischaemia with vasopressor drugs. Stroke 1972;3:135-40.

6 Waltz AG. Effect of blood pressure on blood flow in ischaemic and nonischaemic cerebral cortex. Neurology 1968;18:1069-83.

7 Fenske A, Kohl J, Regli F, Reulen HJ. The effect of arterial hypertension on focal ischaemic edema. $J$ Neurol 1978;219: 241-51.

8 Bleyaert AL, Sands PA, Safar P, et al. Augmentation of post ischaemic brain damage due to severe intermittent hypertension. Crit Care Med 1980;8:41-7.

9 Kogure K, Bustro R, Scheinberg P. The role of hydrostatic pressure in ischemic brain edema. Ann Neurol 1981;9:273-82.

10 Fernandez LA, Spencer DD, Kaczmar T. Angiotensin II decreases mortality rate in gerbils with unilateral carotid ligation. Stroke 1986;17:82-5.

11 Fujimoto T, Walker JT, Spatz M, Kaltzo I. In: Pappius HM, Feindel W, eds. Dynamics of Brain Edema. Berlin: Springer Verlag, 1976:171-80.

12 White OB, Norris JW, Hachinski VC, Lewis A. Death in early stroke; causes and mechanisms. Stroke 1979;10:743.

13 Bosma MJ, Paschen W, Hossmann KA. Cerebral Ischaemia in Gerbils using a Modified Vascular Occlusion Model. In: Meyer
JS, Lechner H, Reivich M, Ott EO, Aranibar, A, eds. Cerebral Vascular Disease 3. Amsterdam: Excerpta Medica, 1981:280-5. 14 Tamura A, Graham DI, McCulloch J, Teasdale GM. Focal cerebral ischaemia in the rat. Description of technique and early neurophysiological consequence following middle cerebral artery occlusion. J Cerebr Blood Flow Metabol 1981;1:53-60.

15 Djuricic BM, Paschen W, Bosma HJ, Hossmann KA. Biochemical changes during graded brain ischaemia in gerbils. $J$ Neuro Sci $1983 ; 58: 25-36$.

16 Elliot KAC, Jasper HH. Measurement of experimentally induced brain swelling and shrinkage. Am J Physiol 1949;157:122-9.

17 Dietis A, Ehtseshami S, Harrison MJG, Perinapanayam NI. The effect of isolvolaemic haemodilution and intravenous glycerol on the sequelae of middle cerebral artery occlusion in the rat. $J$ Neurol Neurosurg Psychiatry 1986;49:428-30.

18 Miller GL. Protein determination for large numbers of samples. Analyt Chem 1959;31:964.

19 Ross Russell RW, Simcock JP, Wilkinson IMS, Frears CC. The effect of blood pressure changes on the leptomeningeal circulation of the rabbit. Brain 1970;93:491-504.

20 Denny-Brown $D$. The treatment of recurrent cerebrovascular symptoms and the question of "vasopressor". Med Clin N Am 1951;35:1457-74.

21 Yatsu FM, Pettigrew LC, Grotta JC. Medical Therapy of Ischemic Strokes. In: Barnett HJM, Mohr JP, Stein BM, Yatsu FM, eds. Stroke Vol 2. London: Churchill Livingstone, 1986:1069-83.

22 Ito $U$, Ohno $\mathrm{K}$, Yamaguchi $\mathrm{T}$, Takei $\mathbf{H}$, Tomita $\mathbf{H}$, Inaba $\mathrm{Y}$. Effect of hypertension on blood-brain barrier changes after restoration of blood flow in post ischemic gerbil brains. Stroke 1980;11:606-11.

23 O'Brien MD, Jordan MM, Waltz AG. Ischemic cerebral edema and the blood brain barrier. Arch Neurol 1974;30:461-5.

24 Tyson GW, Teasdale GM, Graham DI, McCulloch J. Cere brovascular permeability following MCA occlusion in the rat. J Neurosurg 1982;57:186-96.

25 Hossmann K-A, Matsuoka Y. Influence of tissue osmolality on intracerebral fluid shifts and the development of ischemic brain edema. In: Reivich M, Hurtig HI, eds. Cerebrovascular Dis eases. New York: Raven Press, 1983:183-94.

26 Todd NV, Picozzi P, Crockard A, Ross Russell RW. Duration of ischemia influences the development and resolution of ischemic brain edema. Stroke 1986;17:466-71.

27 Avery S, Crockard HA, Ross Russell RW. Evolution and resolution of oedema following severe temporary cerebral ischaemia in the gerbil. J Neurol Neurosurg Psychiatry 1984;47:604-10.

28 Siesjo BoK. Cell damage in the brain: a speculative synthesis. $J$ Cerebr Blood Flow Metab 1981;1:155-85.

29 Matakas F, Eibs G, Cuypers J. Effect of systemic arterial blood pressure on cerebral blood flow in intracranial hypertension. $J$ Neurol Neurosurg Psychiatry 1975;38:1206-10.

30 Ellison MD, Povlishock JT, Hayes RL. Examination of the blood to brain transfer of $\alpha$-aminobutyric acid and horseradish peroxidase. Regional alterations in blood-brain barrier function following acute hypertension. J Cerebr Blood Flow Metab 1986;6:471-80.

31 Klatzo I. Neuropathological aspects of brain edema. $J$ Neuropathol Exp Neurol 1972;26:1-14.

32 Plum F. Brain swelling and edema in cerebrovascular disease. Res Pub Ass Nerv Ment Dis 1968;41:318-48.

33 Harrison MJG, Ell P. Ischemic edema in stroke. Stroke 1981;12:888.

34 Hossmann K-A, Schuier FJ. Experimental brain infarcts in cats. 1. Pathophysiological observations. Stroke 1980;11:583-92.

35 Brown FD, Hanlon K, Mullan S. Treatment of aneurysmal hemiplegia with dopamine and mannitol. $J$ Neurosurg 1978;49:525-9.

36 Muizelaar JP, Becker DP. Induced hypertension for the treatment of cerebral ischemia after subarachnoid hemorrhage: direct effect on cerebral blood flow. Surg Neurol 1986;25: 317-25. 